\title{
SCIENTIFIC METHOD AS THE FOUNDATION OF SCIENTIFIC RESEARCH
}

\author{
KOVAČIĆ POPOVIĆ Anita ${ }^{1}$ \\ ${ }^{1}$ Medika College for Vocational Studies in Healthcare, Belgrade (SERBIA) \\ E-mail: anitakovacic987@hotmail.com
}

\begin{abstract}
The methodology deals with the methods of acquiring scientific knowledge, i.e. all aspects of scientific research as a method of gaining scientific knowledge about phenomena and processes. Scientific method enables gaining scientific knowledge by applying a series of principles, rules and procedures. Every research includes several general scientific methods. Hypothetical-deductive scientific method of acquiring knowledge and modeling method characterize empirical research, while comparative and analytical-deductive methods are applied in theoretical research. It is impossible to carry out research without a data collection method. Therefore, it is necessary to precisely define the methods, techniques and instruments that will be applied in research to gain new scientific knowledge.
\end{abstract}

Keywords: Scientific Method, Scientific Research, Methodology, Science

\author{
JEL:C10 \\ DOI: $10.5937 /$ intrev2102013K \\ UDC: 001.8
}

COBISS.SR-ID 43481353 


\section{INTRODUCTION}

The word method originates from the Greek word "methodos", meaning way of research. It is defined as a way of research applied in certain field of science. A scientific discipline that studies scientific method is called methodology. Methodology, as a branch of logic, studies the ways in which research is to be undertaken applicable in all areas (general methodology) and those applicable in specific sciences (special methodologies). We cannot imagine science without methods, as every scientific method has certain logical, epistemological and technical aspects. The logical aspect is manifested in using basic forms of thinking in the process of acquiring scientific knowledge. The epistemological aspect or theoreticalmethodological approach allows us to gain new knowledge. This part contains general scientific methods and is special for each science, as it depends on the subject the science studies [1]. The third aspect is research technique comprising data collection methods and techniques. These three aspects lead to objective scientific knowledge, and are an integral part of the hypothetical-deductive scientific method of acquiring knowledge.

\section{THE IMPORTANCE OF SCIENTIFIC METHOD IN RESEARCH}

Scientific method is the foundation of scientific research. The methodology most often uses terms such as: method, scientific method, method of science, research method, method of acquiring scientific knowledge. The use of different terms indicates different understandings of its meaning. Starting from the existing definitions of scientific method, Table 1, we can say that scientific method is a way to reach scientific truth. Milic [2] states that the most common and most complete definition is that scientific method is the path toward scientific knowledge. Scientific methods are a key factor in any scientific research, as they are used to carry out research and collect relevant data to discover new scientific knowledge. Radovanović and Stojmirović [3]point that scientific methods occupy a central place in the conceptual design of research and their choice primarily depends on the structure and character of the subject of research.

Table 1. Examples of scientific method definitions

\begin{tabular}{|c|c|}
\hline Definition & Source \\
\hline $\begin{array}{l}\text { A method can be defined as a way of research to reach scientific truth about the problem } \\
\text { it studies. }\end{array}$ & Zaječaranović, 1977: 15[4] \\
\hline $\begin{array}{l}\text { The method of science is a constitutive part of science which ensures relatively true } \\
\text { knowledge about the subject of science. This part of science is determined (conditioned) } \\
\text { by the subject of science, its own properties, structure and relationships, relationships and } \\
\text { development of science and its method in a certain period of time. }\end{array}$ & Milić, 1978: 24[5] \\
\hline $\begin{array}{l}\text { Scientific method is the path, the way in which the basic goal of science - scientific } \\
\text { knowledge - is achieved. As such, it encompasses all logical rules and logical criteria of } \\
\text { scientific knowledge applied by science in general (in that respect there is a certain degree } \\
\text { of unity with arguable boundaries) and each science field separately, and technical means } \\
\text { used in scientific work. }\end{array}$ & Flere, 1982: 359-360[6] \\
\hline $\begin{array}{l}\text { Method is a way of thinking and researching in science. Scientific method is used to } \\
\text { acquire the truest possible knowledge. In the broadest sense of the word method includes } \\
\text { three basic components: general approach to research (principles of scientific cognition), } \\
\text { methodological research procedure (stages of research procedure), research methods and } \\
\text { techniques. }\end{array}$ & Mihailović, 2004[7] \\
\hline $\begin{array}{l}\text { Method of acquiring scientific knowledge is a meaningfully and purposefully, rationally } \\
\text { formed system of ideas, concepts, actions (procedures) and means selected according to } \\
\text { scientific criteria and scientifically tested in acquiring scientific knowledge or carrying out } \\
\text { scientific research on the subject or method of science. }\end{array}$ & $\begin{array}{l}\text { Milosavljević, Radosavljević, } \\
\text { 2006[8] }\end{array}$ \\
\hline $\begin{array}{l}\text { Scientific method is understood as a systemic whole of concepts and ways of researching } \\
\text { a subject of science. }\end{array}$ & Miljević, 2007: 67[1] \\
\hline $\begin{array}{l}\text { Scientific method is a way of thinking and undertaking procedures of researching reality } \\
\text { that guarantees acquiring true and objective knowledge. }\end{array}$ & $\begin{array}{l}\text { Pantelić-Vujanić, Čukanović- } \\
\text { Karavidić, 2014: 14[9] }\end{array}$ \\
\hline $\begin{array}{l}\text { Scientific method implies the application of theory (principles, standards, rules) and } \\
\text { various practical procedures in scientific research to discover and expose a truth about a } \\
\text { subject of research. }\end{array}$ & $\begin{array}{l}\text { Adamović, Ivić, Vuković, } \\
\text { 2017: } 8[10]\end{array}$ \\
\hline
\end{tabular}

In the methodology of scientific research there are numerous methods classified in different ways by the authors. Radovanović and Stojmirović [3]say that the leading authors offer sets of mutually inconsistent methods of scientific research, with some authors identifying a small number of methods, up to five, and others 
suggesting a significantly higher number, up to fifty. The same authors draw attention to the fact that this is not about mistakes, but about how and how deeply the authors understand the ways of scientific development. The most common criteria used in literature about methodology are the generality of methods and the subject researched by the method. Gordić, Termiz and Tančić [11]divide methods by generality criterion into: general methods (trial and error method, method of proofs and refutations and scientific research), basic methods (analysis and synthesis, abstraction and concretization, specification and generalization, induction and deduction), general scientific methods (hypothetical-deductive method, statistical method, modeling method, analytical-deductive method and axiomatic method) and data collection methods (observation, testing, experiments, documentary analysis and case study). However, existing literature on methodology gives division into basic, general scientific and special methods (Table 2). This structure of methods classification can be found in the works of Milosavljević and Radosavljević [8],Miljević [1] and Šešić [12]. In his work, Šešić called the basic methods special methods and tried to unite them under the common name of analytical-synthetic methods. Also, Miljević called basic methods special or basic special methods and singles out a group of operational methods. Data collection methods and data processing methods, between which there is a pronounced interdependence resting upon data characteristics, are sometimes given as special groups of methods [8]. Special methods of social sciences often include positivism, structuralism, dialectical method, and axiologism. This division is based on the criterion of belonging to certain theoretical and methodological directions. When talking about the classification by subject, we distinguish between the methods of all sciences, the methods of natural sciences (methods of still and living nature and methods of man as a natural living being), methods of social sciences and methods of psychology. Within each of these sciences, there are numerous individual, separate and special sciences and scientific disciplines. Furthermore, the structure criterion allows us to distinguish between methods that have and methods that do not have built systems of instruments and instrument handling, which would include methods of empirical and theoretical research. Dividing methods by role and function would refer to conceptualization methods, data collection methods and data processing methods. Then, research methods, in the broadest sense, can be divided into theoretical-systemic, which generalize other theoretical findings, and empirical-experiential methods, which collect facts[13] .

Table 2. Examples of scientific method classifications by the criterion of generality

\begin{tabular}{|c|c|c|c|c|}
\hline Methods & Šešić, 1974[12] & $\begin{array}{c}\text { Milosavljević, } \\
\text { Radosavljević, 2006[8] }\end{array}$ & Miljević, 2007 [1] & Petković, 2010[14] \\
\hline Basic & $\begin{array}{l}\text { Positivism, method of } \\
\text { understanding, } \\
\text { comparative method, } \\
\text { method of ideal types, } \\
\text { method of structuralism } \\
\text { and functionalis, } \\
\text { dialectical methods. }\end{array}$ & $\begin{array}{l}\text { Analysis, synthesis, } \\
\text { abstraction, } \\
\text { concretization, } \\
\text { specialization, } \\
\text { generalization, } \\
\text { deduction, induction, } \\
\text { analogy (comparative } \\
\text { method). }\end{array}$ & $\begin{array}{l}\text { Analysis, synthesis, } \\
\text { abstraction, } \\
\text { concretization, } \\
\text { specialization, } \\
\text { generalization, } \\
\text { deduction, induction, } \\
\text { analogy (comparative } \\
\text { method). }\end{array}$ & \\
\hline $\begin{array}{l}\text { General } \\
\text { scientific }\end{array}$ & $\begin{array}{l}\text { Statistical method, } \\
\text { modeling method, } \\
\text { analytical- deductive } \\
\text { method. }\end{array}$ & $\begin{array}{l}\text { Statistical method, } \\
\text { modeling method, } \\
\text { axiomatic method, } \\
\text { analytical-deductive, } \\
\text { hypothetical-deductive } \\
\text { method. }\end{array}$ & $\begin{array}{l}\text { Statistical method, } \\
\text { modeling method, } \\
\text { axiomatic method, } \\
\text { analytical-deductive, } \\
\text { hypothetical-deductive } \\
\text { method. }\end{array}$ & Dialectical, metaphysical. \\
\hline $\begin{array}{l}\text { Special } \\
\text { scientific }\end{array}$ & $\begin{array}{l}\text { Analytical-synthetic, } \\
\text { abstraction and } \\
\text { concretizatio, } \\
\text { generalization and } \\
\text { specializatio, } \\
\text { classification, induction } \\
\text { and deduction. }\end{array}$ & $\begin{array}{l}\text { Positivism, structuralis, } \\
\text { axiologism, dialectical } \\
\text { method, etc. }\end{array}$ & $\begin{array}{l}\text { Structuralis, } \\
\text { axiologism, dialectical } \\
\text { method, etc. }\end{array}$ & $\begin{array}{l}\text { Analysis, synthesis, } \\
\text { abstraction and } \\
\text { concretization, } \\
\text { generalization and } \\
\text { specialization, induction and } \\
\text { deduction; Methods, } \\
\text { techniques and instruments } \\
\text { of scientific research; } \\
\text { Technical methods and } \\
\text { instruments. }\end{array}$ \\
\hline $\begin{array}{l}\text { Data } \\
\text { collection or } \\
\text { operational }\end{array}$ & - & - & $\begin{array}{l}\text { Examination, } \\
\text { observation, } \\
\text { experiment, } \\
\text { documentary analysis, } \\
\text { case studies. }\end{array}$ & th \\
\hline
\end{tabular}

We can say that the basic methods are the most general, as they permeate all other methods. Milosavljević and Radosavljević [8]believe that the historical-comparative method as well should be found within the basic 
methods. General scientific methods are directly or indirectly applied in sciences and scientific disciplines. Hypothetical-deductive, statistical and modeling method are most often used in the social sciences, analyticaldeductive somewhat less often and axiomatic least often [11]. By special methods we mean thinking-logical procedures in research, which are also called basic special methods in literature. Some authors single out in special methods a subgroup of methods related to certain sciences, which include positivism, structuralism, dialectical method, axiologism, etc. Data collection methods or operational methods stand out as special groups of methods. We can say that scientific methods are classified by practical purpose, as not all methods are applicable in all sciences. In special scientific methods category, Petković [14] singles out a subgroup of auxiliary methods, where he includes historical method, comparative method, statistical-mathematical method, single case study method, content analysis, sociometry and the Delphi method. Then, within the same category of special scientific methods, there are technical methods and instruments that include observation, interview, survey and test. By observing the division of methods, where the four most common categories are singled out, we could classify technical methods and instruments into data collection methods. Data collection method collects data for the purposes of scientific research. This method is directly related to data processing method. Most often, authors classify testing methods, observation methods and experimental methods in these methods. In addition to these, this group can also include documentary analysis method and case study method. Gordić, Termiz and Tančić[11] point out that the nature and characteristics of certain researched phenomena condition the application of some common methods. One method of scientific research can have several research techniques, which is pronounced in data collection methods. In research of all types of phenomena, testing, observation and experiment can be used, but the results are of different validity and reliability. Therefore, with natural sciences, experiment and observation take precedence over examination, while in social sciences, examination cannot be disregarded.

Scientific method has the role of providing a form of scientific research through the logical rules inherent in a particular method, as well as the content that arises from the epistemological work on which the scientific method relies and without which methodological research would not be possible. Using certain scientific methods during the scientific research process, new knowledge is discovered, but in a way that is defined as a property of the methods and that is repeatable and thus ensures process reliability and verifiability of results and scientific truth. The basic characteristics of research are a clear formulation of the research problem and focus on a specific goal. To achieve these basic characteristics, research needs to be well designed and undertaken according to the set plan, i.e. a certain scientific method. Hence the classification of research by the criteria of applied methods. The first group of this classification includes experimental research in which experimental method is dominant. Survey research, in which the dominant method is examination of samples of respondents. Observational research is dominated by method of observation and multimethod which combines various methods in a relatively equal status. The second classification group of research consists of those that belong to various theoretical and methodological directions and approaches, and include: positivist, structuralist, functionalist, behaviorist and dialectical research [11]. Each methodological orientation also contains its own methods, but some of these methodological directions, although designed for certain sciences, can be applied in the research of any subject, any science [8]. We can note that positivism, structuralism and dialectical method can be successfully applied in both natural and social sciences.

The basic theoretical and methodological directions in understanding scientific knowledge have contributed to the development of the basic methods of scientific research and setting of the basic rules of scientific research, which make up the very structure of scientific research. The basic elements of scientific method are also the phases of research procedure which begins with defining the research problem, i.e. subject of research. The research problem is a connection between the theoretical and methodological part of scientific research work and it is solved by consistent application of scientific method. Every scientific knowledge acquiring begins and progresses by setting hypotheses, and at the same time it is the most important component of hypothetical-deductive scientific method of acquiring knowledge [15]. Hypotheses are assumptions about the solutions of a certain scientific problem and by setting them, researcher decides on the type of research and data collection method. Termiz and Milosavljević [16] claim that hypotheses have a certain structure comprising dependent and independent variable, as well as the relationship between them, which is expressed as the position of the hypothesis. Knowledge acquiring role of hypotheses is determined by the scientific goals from which it derives. The whole research process is focused on testing hypotheses, and the role of scientific method is to set scientific criteria. 


\section{CONCLUSION}

Scientific method as a way of acquiring reliable knowledge is the structure of every scientific research. Scientific methods classification has a significant share in the literature published so far. However, the classifications presented are rather heterogeneous, as is the very definition of scientific method. Some authors are guided by the idea that scientific method is the path toward scientific knowledge, while other group points out that it also refers to the very procedures of acquiring knowledge. From this follow different criteria for classifying scientific method. The criteria most often used in classification include generality, subject, structure, function and belonging to theoretical-methodological directions. Each of these criteria gives a classification of methods, which, on its part, varies depending on the author and the purpose of using. From all the above, we can conclude that scientific method is the foundation of any research, that it is a way to reach scientific truths, and that it includes the ways in which data will be collected and processed. It gives us a clear structure to scientific research in which logic and meaningfulness are respected.

\section{REFERENCES}

[1] Miljević, M. (2007). Metodologija naučnog rada. Filozofski fakultet: Univerzitet u Istočnom Sarajevu Pale.

[2] Milić, Vojin (1996). Sociološki metod. Beograd: Zavod za udžbenike.

[3] Radovanović, T., Stojmirović, Lj. (2014). Metodologija naučnog istraživanja. Novi Sad: Fakultet za ekonomiju i inžinjerski menadžment.

[4] Zaječaranović, G. (1977). Osnovi metodologije nauke. Beograd: Naučna knjiga.

[5] Milić, Vojin (1978). Sociološki metod. Beograd: Nolit.

[6] Flere, S. (1982). Sociološki leksikon. Beograd: Savremena administracija.

[7] Mihailović D. (2004). Metodologija naučnih istraživanja. Beograd: Napredak.

[8] Milosavljević, S., Radosavljević, I. (2006). Osnovi metodologije političkih nauka. Beograd: Službeni glasnik.

[9] Pantelić-Vujanić, S., Čukanović-Karavidić, M. (2014). Sociologija. Banja Luka: Univerzitet za poslovni inženjering i menadžment.

[10] Adamović, Ž., Ivić, M., Vuković, V. (2017). Metodologija i tehnologija izrade naučnih radova. Banja Luka: Univerzitet za poslovni inženjering i menadžment

[11] Gordić, M., Termiz, DŽ., Tančić, D. (2015). Metodološki osnovi istraživanja bezbednosti odbrane i terorizma. Banja Luka: Evropski univerzitet Brčko Distrikta.

[12] Šešić, B. (1974). Osnovi metodologija društvenih nauka. Beograd: Naučna knjiga.

[13] Bogdanović, M. (1981). Kvantitativni pristup u sociologiji. Beograd: Službeni list SFRJ.

[14] Petković, V. (2010). Metodologija naučnog istraživanja. Beograd:Visoka škola za poslovnu ekonomiju i preduzetništvo.

[15] Savić J. (2013). Metodologija naučnog saznanja i Kako stvoriti naučno delo u biomedicini. Beograd: Data Status.

[16] Termiz, Dž., Milosavljević, S. (1999). Uvod u metodologiju politikologije. Sarajevo: DAX Trade.

\section{Article history:}

Received 11 March 2021

Accepted 31 May 2021 